\title{
PROGRAM PENGGEMUKAN TERNAK DOMBA EKOR GEMUK DI KECAMATAN SEMANDING, KABUPATEN TUBAN
}

\section{PROGRAM FOR FATTENING FAT-TAILED SHEEP IN THE DISTRICT OF SEMANDING, TUBAN REGENCY}

\author{
Indah Norma Triana \\ Fakultas Kedokteran Hewan, Universitas Airlangga, Kampus C Mulyorejo, Surabaya, 60115, \\ Tel/fax: +62-31-5992-785/+62-31-5993-015 E-mail: indah_norma@yahoo.com
}

\section{Rr. Ratih Ratnasari}

Fakultas Kedokteran Hewan, Universitas Airlangga, Kampus C Mulyorejo, Surabaya, 60115, Tel/fax: +62-31-5992-785/+62-31-5993-015

\section{Ajik Azmijah}

Fakultas Kedokteran Hewan, Universitas Airlangga, Kampus C Mulyorejo, Surabaya, 60115, Tel/fax: +62-31-5992-785/+62-31-5993-015

\begin{abstract}
Abstrak
Program penggemukan dan budidaya ternak domba ekor gemuk (EG) di Kecamatan Semanding, Kabupaten Tuban merupakan bentuk kerja sama antara Lembaga Pengabdian Kepada Masyarakat Universitas Airlangga dengan Kelompok Ternak Gemah Ripah dan Mandiri, Tuban. Pelaksanaan program ini melibatkan dokter hewan, yang merupakan ahli reproduksi, ahli pakan ternak, ahli kesehatan ternak serta ahli sanitasi dan perkandangan, serta dibantu oleh tenaga lokal. Kegiatan yang dilakukan antara lain meliputi: pelatihan budidaya ternak domba EG, peragaan pembuatan pakan dan kandang, pemberian vaksin, pemeliharaan pra- dan pasca- produksi, serta pemeriksaan dan pengobatan domba yang sakit. Pada kesempatan ini, juga diperkenalkan obat untuk penggemukan domba, yaitu: Bio-N-Plus, Premix Mineral, dan vitamin B-Kompleks. Bahan tersebut diberikan dengan tujuan untuk mempercepat pertumbuhan domba. Selain itu, juga dilakukan simulasi beternak domba EG bagi para peternak. Pada akhir pelatihan telah diberikan paket ternak domba EG kepada kelompok peternak Gemah Ripah Dan Mandiri, yaitu berupa: 6 ekor domba EG, 3 kwintal pakan konsentrat yang bisa digunakan untuk empat bulan, biaya renovasi kandang domba EG, serta vitamin, obat-obatan, dan vaksin. Dari hasil pelaksanaan program ini, para peternak telah berhasil memelihara domba EG dengan cara yang lebih baik dengan tanda pertumbuhan berat badan ternak yang semakin meningkat, serta tidak ada resiko sakit dan kematian hewan ternak.
\end{abstract}

Kata kunci: domba ekor gemuk, peningkatan berat badan, Bio-N-Plus, Premix Mineral, simulasi beternak domba EG

\section{Abstract}

The program for fattening and breeding of fat-tailed sheep (EG) in Semanding District, Tuban Regency, was collaboration work among Institute for Research and Community Service (LPPM) of Universitas Airlangga, Gemah Ripah, and Mandiri's Breeding Coomunity, Tuban Regency. The program was conducted by veterinarians, who are experts in animal reproduction, animal feeding and health, camping and its sanitation, assisted by local people. The activities included training on livestock breeding, demonstration of animal feeding and caging, vaccination, livestock maintenance at pre-and post-production, and also the health examination and treatment of sick fat-tailed sheep. There was also presentation about medicines used for animal fattening, i.e. Bio-N-Plus, Premix Minerals, and vitamin B-Complex. These drugs were given to the participants to accelerate the cattle growth. In addition, a simulation on how to breed fat-tailed sheep was also demonstrated to the participants. At the end of the program, a package was given to Gemah Ripah dan Mandiri's Breeding Community. It consisted of six fat-tailed sheep, 3 quintals of concentrate feeds used for about four months feeding, the money for renovating the animal cages, vitamins, medicines, and vaccines. This training program was successfully increased the ability of participants, Gemah Ripah and Mandiri's Breeding Coomunity, to breed the fat-tailed 
sheep in a relatively good way. It was supported by the facts that the cattle had increased body weights and there was no observed risk of sickness and animal death.

Keywords: fat-tailed sheep, increased body weight, Bio-N-Plus, Premix Mineral, simulation on animal breeding

\section{PENDAHULUAN}

Guna memenuhi kebutuhan pangan dan gizi bagi masyarakat, khususnya kebutuhan protein hewani yang bersumber dari daging, maka subsektor peternakan sebagai salah satu bagian dari pembangunan pertanian harus dikembangkan. Dengan demikian, peluang pasarnya selalu tersedia setiap saat dan meningkat setiap tahun seiring dengan pertambahan jumlah penduduk dan meningkatnya kebutuhan gizi.

Berdasarkan data yang ada, Indonesia memiliki kondisi alam yang baik untuk budidaya domba hingga 10 kali jumlah ternak yang ada sekarang dan memiliki kesempatan untuk melakukan ekspansi ke luar negeri dengan adanya era perdagangan bebas (Yusdja 2004). Selain itu, usaha beternak domba, khususnya domba ekor gemuk (EG) memiliki banyak keuntungan, antara lain: dapat dilakukan secara efisien pada lahan yang sempit, daya adaptasi domba yang tinggi terhadap berbagai kondisi lingkungan sehingga mudah dipelihara dan dikembangkan, masa perkembang-biakan yang tergolong cepat yaitu sekitar 1,5 tahun untuk yang pertama dan 7-8 bulan untuk periode berikutnya, serta memiliki kandungan protein yang tinggi. Dari segi keuangan, beternak domba lebih memberikan keuntungan daripada jenis ternak lainnya. Bahan pakan domba dapat diberikan dengan memanfaatkan limbah pertanian sebagai pakan, misalnya limbah hasil panen jagung, limbah hasil panen dari golongan kacang-kacangan, dan lainlain. Selian itu, modal yang diperlukan relatif lebih kecil dibandingkan dengan memelihara ternak besar, dengan hasil yang lebih besar. Ternak domba juga merupakan sumber uang tunai karena penjualannya mudah (Diwyanto 2005, Rusdiana dkk. 2014). Dengan demikian, pada usaha berskala besar, ternak domba dapat membuka lapangan pekerjaan baru bagi masyarakat untuk membantu meningkatkan kesejahteraan dan pengentasan kemiskinan.

Walaupun banyak keuntungan yang dapat diperoleh dari beternak domba EG, namun pengembangannya sebagai salah satu ternak potong masih banyak mengalami hambatan. Hal ini dikarenakan pemeliharaannya yang masih dilakukan secara tradisional. Pemberian pakan seringkali dilakukan dengan sekedarnya saja, tanpa mempertimbangkan kebutuhan standar gizi ternak. Bahkan sering dijumpai domba yang dilepas begitu saja untuk mencari makan sendiri. Tehnik pemeliharaannya tidak terprogram dengan baik dan kandangnya hanya dibuat ala kadarnya, sebagai tempat berlindung dari teriknya matahari di waktu siang dan udara dingin di waktu malam. Tehnik pemeliharaan secara tradisional ini jelas kurang menguntungkan karena mengakibatkan domba EG tidak dapat berproduksi secara maksimal, dimana domba tetap kecil dan kurus (Soepeno dan Manurung 1996). Hal ini disebabkan karena tidak adanya pengawasan yang baik tentang makanan, baik jumlah maupun kualitasnya. Terlebih lagi, perhatian terhadap mutu bibit domba juga kurang karena tidak ada tahapan seleksi yang baik dan tingkat kematian karena penyakit lebih tinggi. Padahal, apabila pemeliharaannya dilakukan secara intensif sebagai ternak pedaging, berat badannya dapat mencapai 40 $60 \mathrm{Kg}$.

Pemeliharaan domba secara intensif dapat dilakukan melalui pemeliharaan dalam kandang yang sesuai dengan persyaratan teknis. Pemberian pakan (ransum) sesuai dengan standar kebutuhan gizi ternak dan disediakan dalam jumlah yang cukup. Pengawasan dilakukan secara cermat dan teliti, baik terhadap ternak yang sehat maupun yang sakit. Tata laksana pemeliharaan lebih terencana dengan menggunakan manajemen yang baik. Pemeliharaan domba secara intensif ini dapat dilakukan dalam kandang model baterei ataupun dalam kandang model postal (terkurung) yang diberi umbaran terbatas agar dapat bermain-main. Dengan pemeliharaan secara intensif, domba menjadi lebih produktif karena tidak banyak bergerak sehingga energinya dapat digunakan untuk meningkatkan metabolisme tubuh, khususnya untuk memproduksi daging. Selain itu, tehnik pemeliharaan secara intensif ini dapat memudahkan untuk pemberian pakan dan minum, pembersihan kandang, pengawasan dan perawatan terhadap hewan yang sakit, sehingga kesehatan ternak yang dipelihara lebih terjamin, serta dapat lebih menghemat tenaga kerja (Masrah dkk. 2016).

Pada kegiatan ini, dilakukan pelatihan sehari dengan topik program penggemukan domba EG kepada kelompok budidaya ternak Gemah Ripah dan Mandiri, serta para penduduk lokal di Kecamatan Semanding, Kabupaten Tuban. Selain itu, juga dilakukan praktik lapangan mengenai pembuatan kandang serta pemberian modal kepada kelompok peternak tersebut sebagai modal awal pengembangan usaha budidaya ternak domba EG untuk pemberdayaan ekonomi masayarakat setempat.

\section{METODE PELAKSANAAN}

Dalam kegiatan ini, pelaksanaan pelatihan program pengegmukan domab EG terbagi atas beberapa tahap yaitu meliputi: (1) orientasi daerah/lapangan, (2) pengurusan perijinan, (3) pelatihan ternak domba EG, (4) Pembuatan 
dan renovasi kandang domba EG, (5) pengadaan pakan konsentrat dan obat-obatan, (6) pengadaan domba EG, dan (6) pemantauan domba EG secara rutin.

Penentuan lokasi desa yang akan dipakai untuk budidaya ternak domba EG di kecamatan Semanding kab. Tuban ini melibatkan beberapa nara sumber antara lain: camat, kepala desa, pengurus cabang dinas pertanian (peternakan) setempat serta tokoh pemuka masyarakat, dan alim ulama. Adapun kriteria yang diajukan dalam menentukan desa untuk dipakai penggemukan domba EG yaitu: pengalaman warga masyarakat dalam memelihara Domba EG, minat serta keseriusan masyarakat dalam beternak domba, serta kondisi topografi daerah yang relatif mudah untuk pemasaran.

Pengurusan perijinan dilakukan sebelum pelatihan maupun pelaksanaan di lapangan. Perijinan ini dimaksudkan untuk memudahkan koordinasi antara aparat terkait dengan tim pelaksana pelatihan, yaitu meliputi perijinan di kecamatan maupun di lokasi desa pelaksanaan program penggemukan domba EG. Setelah didapatkan ijin baik dari kecamatan maupun desa, selanjutnya telah dilakukan koordinasi terkait hari pelaksanaan pelatihan budidaya ternak domba EG.

Materi mengenai budidaya ternak domba EG yang diberikan pada pelatihan ini meliputi: pemilihan bibit domba EG yang baik, perawatan domba EG bakalan, pembuatan kandang sistem panggung, pembuatan dan pencampuran pakan, penggemukan domba EG, pencegahan dan penanggulangan penyakit, serta pemasaran. Selain materi tersebut, juga diberikan alih teknologi dan percontohan inseminasi buatan pada domba EG dalam rangka menciptakan inseminator dan paramedis dengan materi kegiatan antara lain: pengenalan alat kelamin dan teknik deteksi birahi pada domba EG, teknik inseminasi buatan, diagnosa kebuntingan, penanganan infertilitas pada domba EG, teknik sinkronisasi birahi, serta penanganan beberapa penyakit pada domba EG.

Pelatihan ini melibatkan empat instruktur yang semuanya dari tim pelaksana yang berasal dari Fakultas Kedokteran

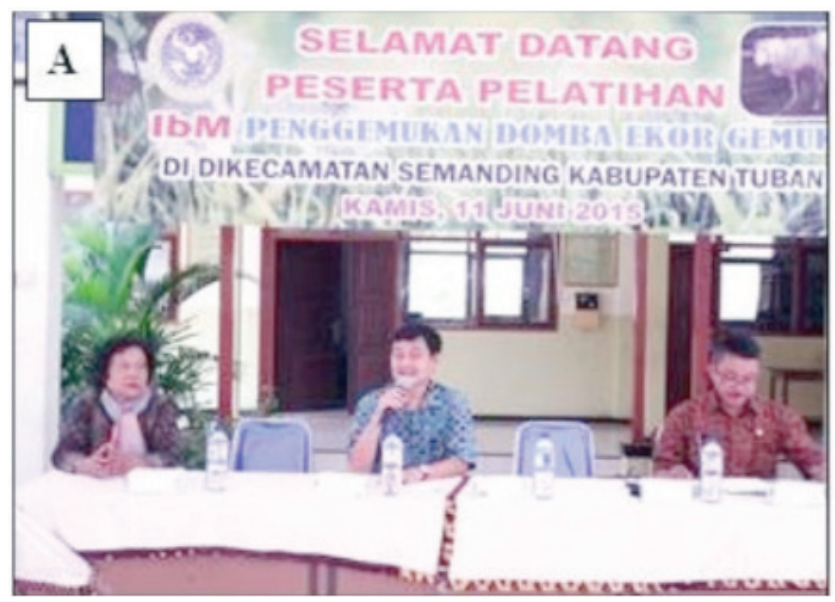

Hewan, Universitas Airlangga. Sebelum berakhirnya pelatihan dilakukan diskusi dan tanya-jawab antara para peserta dan instruktur.

Selain pemberian materi, juga telah dilakukan praktek lapangan mengenai pembuatan dan renovasi kandang, Di akhir kegiatan, telah diberikan paket untuk budidaya ternak domba EG kepada dua kelompok budidaya ternak di daerah tersebut, yaitu kelompok Gemah Ripah dan Mandiri, yang meliputi: ternak domba EG, pakan konsentrat, dan obatobatan,

\section{HASIL DAN PEMBAHASAN}

Pada kegiatan ini, telah dilaksanakan pelatihan penggemukan domba EG di desa Bejagung dan Tunah yang ada di kecamatan Temayang. Dua desa tersebut terletak bersebelahan, kurang lebih $2 \mathrm{~km}$ dari lokasi Kecamatan Temayang. Masyarakatnya sudah berpendidikan minimal SD, serta relatif mudah menerima informasi tentang hal-hal baru, khususnya yang berkaitan dengan bidang pertanian dan peternakan. Pelatihan ini dilaksanakan sehari di Pendopo Kecamatan Semanding, Kabupaten Tuban dan diikuti oleh 50 orang peserta dari desa yang ada di kecamatan Semanding. Disamping itu, pelatihan ini juga dihadiri oleh camat Temayang, pegawai dinas peternakan setempat, kepala desa di lingkungan kecamatan Semanding serta tokoh masyarakat yang ada di lokasi tersebut (Gambar 1).

Berdasarkan hasil pelatihan yang telah diberikan, yang meliputi berbagai materi tentang budidaya domba EG, pembuatan kandang serta pemasaranya, sekitar $80 \%$ peserta dapat mengerti dan menyerap materi yang diberikan serta sangat antusias untuk memelihara ternak domba EG. Setelah kegiatan presentasi materi, juga dilakukan praktik lapangan mengenai pembuatan dan renovasi kandang. Kegiatan ini dilakukan dua hari setelah pelatihan, dimana pada kegiatan ini dilakukan pembuatan 6 buah kandang domba EG (Gambar

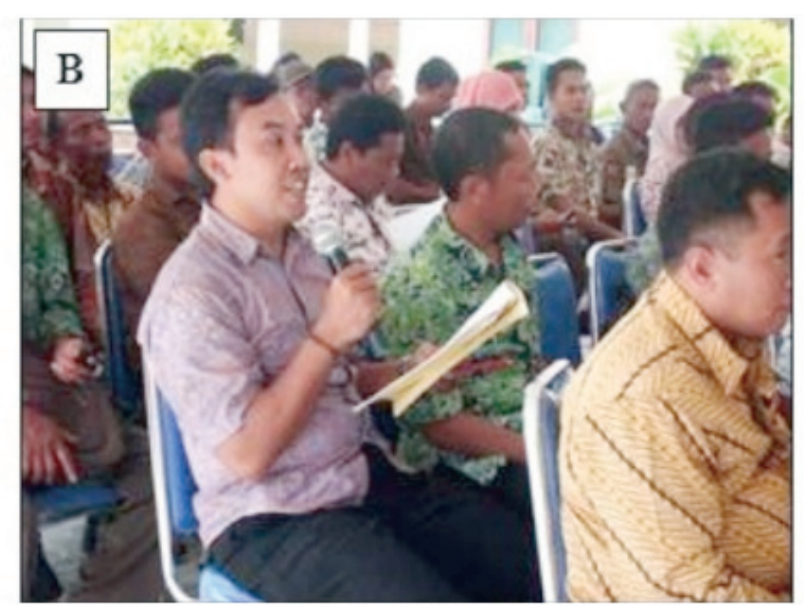

Gambar 1. Pemateri (A) dan peserta (B) kegiatan pelatihan program penggemukan domba EG yang diadakan di Kecamatan Semanding, Kabupaten Tuban. 

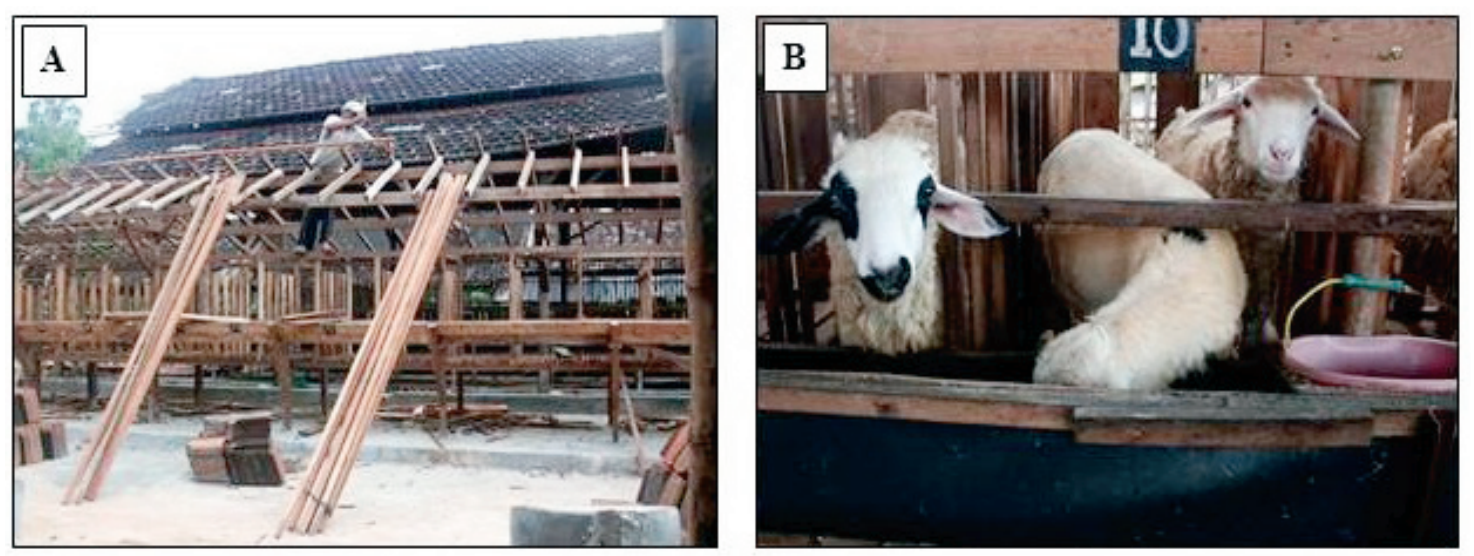

Gambar 2. Kandang (A) dan domba EG (B) yang dibuat dan diserahkan kepada peternak pada kegiatan pelatihan program penggemukan domba EG di Kecamatan Semanding, Kabupaten Tuban.

2). Pembuatan kandang ini meliputi atap, tutup samping maupun panggungnya. Pelaksanaannya memakan waktu kurang lebih 10 hari. Setelah selesai, dilakukan sterilisasi dengan bahan formalin dan $\mathrm{KMnO}_{4}$. Ukuran dari masingmasing kandang tidak sama, disesuaikan dengan luas tanah yang ada.

Pengadaan konsentrat serta obat-obatan dilakukan oleh tim pelaksana. Setiap peternak mendapatkan 4 karung konsentrat dengan berat masing-masing $50 \mathrm{Kg}$ serta obatobatan yang meliputi: vitamin, Bio-N-Plus, Premix Mineral, vaksin, obat diare, serta antibiotik. Pemberian konsentrat ini ditujukan untuk pemeliharaan seekor domba EG selama 4 bulan. Setelah pakan konsentrat habis maka diharapkan peternak dapat membeli sendiri dari hasil keuntungan penjualan domba.

Selain memperoleh pakan dan obat-obatan, peserta kegiatan juga mendapatkan domba EG sebagai modal awal budidaya ternak domba EG. Pengadaan domba EG dilakukan jauh sebelumnya dan berasal dari satu peternakan yang sudah terpantau kesehatan dan kualitas dombanya. Pengadaan Domba ini dilakukan di daerah Gresik, antara lain dari daerah Manyar dan Sedayu. Umur Domba yang diberikan pada kelompok peternak adalah 1 tahun. Domba EG yang didatangkan sudah divaksin secara lengkap dan dalam kondisi siap masuk ke dalam kandang sistem panggung. Saat domba datang pertama kali dan masuk ke dalam kandang panggung, maka akan diberikan vitamin untuk menghilangkan stres selama dalam perjalananm, kurang lebih selama 2 minggu. Selain itu, juga diberikan pakan dalam bentuk konsentrat dan hijauan secara cukup, sedangkan untuk merangsang pertumbuhan berat badan diberikan Growth Stimulant (GS) berupa Bio-N-Plus. Domba EG yang diberikan kepada kedua kelompok ternak (Gemah Ripah dan Mandiri) sebanyak 6 ekor dan pakan konsentrat sebanyak 12 karung.

Setelah domba datang dan masuk kandang panggung, maka dilakukan pemantauan 2 minggu sekali secara rutin.
Tujuan dari pemantauan ini adalah untuk mengetahui kondisi kesehatan dan perkembangan terakhir dari Domba tersebut. Selain itu untuk mengetahui kenaikan rata-rata berat per hari dari domba tersebut. Apabila Domba telah dipelihara selama 2 bulan, maka pemberian mineral dan makanan tambahan berupa rumput dan hijauan lainnya mulai dilakukan untuk meningkatkan kenaikan berat badannya. Setelah Domba dipelihara 5 bulan dan kemudian dijual, maka dibelikan domba lagi dan digulirkan ke kelompok peternak yang lain.

Bahan baku berupa hijauan (rumput, dedaunan) dan dedak/bekatul banyak tersedia di daerah Tuban, khususnya desa Semanding. Untuk itu perlu dilakukan pembuatan pakan sendiri berupa konsentrat dengan komposisi per $100 \mathrm{Kg}$ sebagai berikut: dedak/bekatul $50 \mathrm{Kg}(50 \%)$, bungkil kelapa $25 \mathrm{Kg}(25 \%)$, tepung jagung $15 \mathrm{Kg}$ (15\%), bungkil kacang tanah $8 \mathrm{Kg}(8 \%)$, garam dapur $1 \mathrm{Kg}(1 \%)$, tepung tulang $0,5 \mathrm{Kg}(0,5 \%)$, dan kapur $0,5 \mathrm{Kg}(0,5 \%)$. Selain itu, juga dilakukan pembuatan pupuk kandang dengan mencampurkan kotoran domba dengan bokasi dan biofermentor, kemudian diaduk secara merata. Setelah itu, campuran dijemur selama satu hari untuk menghasilkan pupuk kandang.

Dari hasil evaluasi kegiatan yang dilaksanakan, lebih dari $80 \%$ peserta dapat berhasil dengan baik dalam melaksanakan penggemukan ternak Domba EG yang ditandai dengan kenaikan berat badan yang cukup tinggi serta tidak adanya kematian pada Domba tersebut. Selain itu, setelah menerima pelatihan penggemukan domba EG ini, minat masyarakat calon peternak untuk segera memulai beternak domba EG meningkat. Hal ini ditunjukkan dengan tingginya angka konsultasi oleh peternak dengan tim pelaksana, baik lewat sms maupun e-mail. Namun, dalam pelaksanaan kegiatan ini, masih diperlukan peningkatan frekuensi pemantauan atau kunjungan ke masing-masing lokasi peternak. Selain itu, untuk sebagian peternak yang masih mengalami kendala/ kesulitan, dirasakan perlu dilakukan pembinaan yang lebih intensif lagi,atau jika memungkinkan, dapat dijadikan sebagai daerah binaan oleh Universitas Airlangga. 


\section{SIMPULAN}

Kegiatan pelatihan program penggemukan domba EG telah dilaksanakan dengan sukses di Kecamatan Semanding, Kabupaten Tuban. Melalui kegiatan presentasi materi serta praktik lapangan, telah berhasil diberikan pemahaman dan bekal keterampilan kepada para peserta, khususnya peternak local, mengenai pentingnya budidaya ternak domba EG yang intensif dan sehat. Dengan demikian, budidaya ternak domba EG oleh peternak lokal dapat dilakukan secara maksimal sebagai upaya pemberdayaan ekonomi masayarakat di Kecamatan Semanding, Kabupaten Tuban.

\section{UCAPAN TERIMA KASIH}

Kegiatan ini didanai oleh dana hibah IPTEKS bagi Masyarakat (IbM) dari Kementrian Riset, Teknologi, dan Perguruan Tinggi, Indonesia.

\section{DAFTAR PUSTAKA}

Diwyanto, K., Priyanti, A., Inounu, I. 2005. "Prospek dan Arah Pengembangan Komoditas Peternakan: Unggas, Sapi, dan Kambing-Domba”. Wartazoa, 15:11-25.

Masrah, Hafid, H., Saili, T. 2016. "Kajian Produktivitas Ternak Kambing pada Sistem Pemeliharaan yang Berbeda di Kecamatan Andoolo Barat Kabupaten Konawe Selatan". JITRO, 1: 40-51.

Rusdiana, S., Praharani, L., Adiati, U. 2014. "Prospek dan Perkembangan Strategi Perdagangan Ternak Kambing dalam Merebut Peluang Pasar Dunia". Agriekonomika, 3: 596-615.

Soepeno dan Manurung, J. 1996. "Beberapa Kendala dalam Pemeliharan Ternak Domba/Kambing di Jawa dengan Sistem Ekstensif'. Wartazoa, 5: 17-20.

Yusdja.Y. 2004. "Prospek Usaha Peternakan Kambing Menuju Tahun 2020". Lokakarya Nasional Kambing Potong. Bogor. 